\title{
Economic, physical and psychological violence in Chile $^{1}$
}

\author{
Violencia económica, física y psicológica en Chile
}

\author{
Miguel SÁNChez \\ University of Regina, Canada
}

\begin{abstract}
This article proposes that the experience of Chile demonstrates that the owners of capital (national or international) have not and will not hesitate to use extreme violence to impose a model of capitalist development designed to satisfy the needs of capital: maximum profits. By examining two time perio$\mathrm{ds}$, this article provides examples of the links between organized violence and the creation and development of physical and psychological trauma.

The analysis draws connections between the violence of the Pinochet dictatorship and the contemporary repression used to enable the extraction of timber from traditional Mapuche territory. The article shows how the violence, which was key to the imposition of neoliberalism after the 1973 coup d'état, continues today. The forestry companies privatized and sold by Pinochet to the elite continue to rely on Pinochet-era state forces and repressive tactics to accumulate profits. This article concludes by pointing to the need for academic research on the trauma of today's victims of political violence.
\end{abstract}

KEYWORDS Political violence; profits; political trauma.

RESUMEN Este artículo propone que la experiencia de Chile demuestra que los dueños del capital (nacionales o internacionales) no han dudado y no dudarán en utilizar la violencia extrema para imponer un modelo de desarrollo capitalista diseñado para satisfacer las necesidades del capital: las máximas ganancias. Mediante un examen de dos períodos de tiempo, este articulo ofrece

1. For my cousin Alejandro Garcia Droguet, who desired social justice and was savagely tortured in the National Stadium in 1973. He died prematurely in 2013. 
ejemplos de los vínculos entre la violencia organizada y la creación y desarrollo de traumas físicos y psicológicos.

El análisis establece conexiones entre la violencia de la dictadura de Pinochet y la represión contemporánea utilizada para facilitar la extracción de madera del territorio tradicional mapuche. El artículo muestra cómo la violencia, que fue clave en la imposición del neoliberalismo, después del golpe de Estado de 1973, se mantiene hoy. Las empresas forestales privatizadas y vendidas por Pinochet a la élite, continúan dependiendo del uso de las fuerzas estatales y tácticas represivas de la era de Pinochet para acumular ganancias. Concluye señalando la necesidad de una investigación académica sobre el trauma de las víctimas actuales de la violencia política.

PALABRAS CLAVE Violencia política; ganancias; trauma político.

\section{Introduction}

This paper is written utilizing a transformational research approach. The main objective of the transformational paradigm is to effect structural change. Researchers working from this perspective sustain that society is structured in a way that causes powerlessness and economic exploitation (Westhues et al., 1999). They further believe that social change will occur when people connect "public issues" with "private troubles" (Westhues et al., 1999, p. 139). As I have expressed in previous work, "I accept Peter Roth's assertion that researchers based their projects on a certain sets of assumptions regarding knowledge (epistemology), value (axiology) and reality (ontology)" (Sánchez, 1996, p. 53). One of the analytical tools used by researchers working from the transformational perspective is critical theory. The function of critical theory is not to preserve or reproduce social inequalities, it is to denounce and change them (Marradi et al., 2007). Embedded in this approach this article intends to produce knowledge to facilitate social and economic change.

This article examines the relationship between the expansion of capital in Chile and the creation of politically-motivated physical and psychological trauma towards those opposed to such expansion. Through an examination of two contemporary periods it offers examples of the linkages between organized violence ${ }^{2}$ and the development of physical and psychological trauma. It proposes that political repression has been the main tool to advance and defend the interests of foreign and national capital, and that at different historical moments, the populations targeted for political

2. In this article, organized violence means the political repression used by the capitalist state of Chile to subdue its opponents. The objectives and methods of political repression are described in this page. 
repression fluctuate between the Mapuche and members and/or organizations of the Chilean working class and popular movement.

The objective of political repression, regardless of place and time, is the annihilation of a threat to power through the psychological terrorization of the population (Barudy and Paez, 1979). Torture, imprisonment, exile, and assassination are prominent components of political repression, and they have been used in Chile since the arrival of the Spaniards.

For example, the original inhabitants of Chile, the Mapuche people, put up a heroic resistance to the Spaniards invaders from 1535 until the early 1880s (Collier and Sater, 2004; Llaitul and Arrate, 2012; Zibechi, 2007). Since 1810, they have resisted the attempts of the Chilean state to eliminate them. The Spanish and Chilean armies used atrocious tactics when facing Mapuche resistance. The Spanish for example, amputated the noses and ears of every prisoner before releasing them, and impaled men and women on wooden sticks (De la Pena, 1994; Faundez, 2009; Moyano, 2008).

Following independence, this violence was carried out by the Chilean state. Since the early1900s, the demands of the Mapuche people and of the Chilean working class for land, better salaries, and rights culminated in a series of massacres (Sánchez, 1998). As Klubock (2014) notes, all attempts at social change and political advancement of the popular classes generated moments of confrontation and repression, in twentieth-century Chile. The Chilean arm forces and the military police, (known as Carabineros), were the main instruments of repression from 1818 to 1973 (Salazar, 2009).

They are also the main instruments of repression during the two contemporary periods reviewed, in which massive psychological trauma is purposefully created by capitalism. The first period begins with the coup of September 11, 1973 and ends when the military dictatorship is forced to relinquish executive power in 1990. During this period members of the working class, and of social, political and cultural organizations along with many Mapuche communities were the targets of political repression. The second period begins in 1990, when the first government elected after the dictatorship takes office, until today ${ }^{3}$. During this time the students' movement is the object of repression, sporadically, and the Mapuche communities and organizations, permanently.

3. A review of the entire process of capitalist development in Chile in relation to politically motivated trauma would include at least two other periods in addition to the two examined here. The colonization period from 1530 s to the 1800 s and what it can be called the republican period from 1810 to 1973. 


\section{Dictatorship and the Roots of Contemporary Violence}

The first contemporary period during which organized violence created massive psychological trauma began with the military coup in 1973, and lasted until an elected government was sworn in 1990. The responsibility for the coup lies with the United States government and the Chilean bourgeoisie, who never accepted the profound transformations initiated by the socialist government of Salvador Allende which began in 1970. Foremost among these changes was a wave of nationalization, including the banking and financial companies, the large distribution monopolies, the infrastructure and industries crucial to economic development, all foreign trade, and the mining corporations (Boorstein, 1987; Cademartori, 2000; Collier \& Sater, 2004; Collins, 1974; Petras, n.d.; Raptis, 1974; Salazar, 2009; Soto, 2008; Walder, 2009; Zimbalist \& Stallings, 1973).

The Allende government's actions provoked the ire of the US and its Chilean allies. US and conservative forces in Chile progressively turned class struggle into class war (Miliband, 2015), which culminated with the military violently overthrowing the Allende government.

With the support of the United States and the Chilean and international bourgeoisie, the military became the executors and shapers of a new order characterized by widespread use of violence and terror 4 . Soon after Allende's death the military had Chile under their control and imposed a state of siege that lasted 18 years. The Military Junta headed by Augusto Pinochet closed the Congress and outlawed all Left political and working class organizations. The leaders of the Left and of the working class were asked to surrender, and thousands of Allende's supporters were detained by the Armed Forces.

According to Hite (2005), human rights organizations established that Santiago alone counted with more than eighty detention centres. The locations ranged from schools and public buildings, such as the National Stadium, to secret locations, such as houses and private clubs. For example, Villa Grimaldi was a secret detention and torture centre where more than 5,000 Chileans were tortured and 240 people were killed.

Beginning in 1973, and for almost eighteen years, state terrorism was a permanent feature of daily life. Torture was the favoured instrument to disseminate terror, and it was used routinely to subdue the "subversives" and "conspirators" to the new order (Loveman and Lira, 2005).

4. There are numerous publications inside and outside Chile documenting the atrocities committed by the military and their civilian supporters through the 1970's and 1980's. To illustrate this point, the United Nations General Assembly condemned the Chilean dictatorship annually for its systematic violation of human rights. Amnesty International and other human rights groups, churches, international and professional organizations published many reports confirming that Chilean generals submitted Chile to a generalized state of terror. 
All branches of the Armed Forces intelligence services (Navy, Air Force, Army, Police, and the Detective Police Force), participated in political repression from the beginning until the end of the dictatorship. However, the most prominent repressive organizations during this period of time were the National Directorate of Intelligence (Dirección de Inteligencia Nacional DINA) and the National Information Centre (Central Nacional de Inteligencia CNI). The DINA emerged from within the Army in 1973, and recruited officers from the different branches of the armed forces. According to Agger and Jensen (1996) agents selected for DINA were taught "to spy, to deceive and to kidnap, to interrogate and torture, and to do what was needed to break down any resisting opponent" (p. 50). The DINA became the CNI in 1977; both operated under the direct command of Pinochet until 1990.

The DINA-CNI, as state repressive apparatuses, were responsible for quashing any manifestation of resistance to the dictatorship. They targeted clandestine leftist organizations and joined the military and police in repressing massive demonstrations against the dictatorship which began in the early 1980's. The DINA-CNI operated both inside and outside the country and counted with the support of the CIA and the Brazilian military intelligence services (Guardiola-Rivera, 2013; Moniz, 2008; Verdugo, 2003).

Barudy, Serrano and Martens (1980) write that while working with victims of torture they heard testimonies declaring that specialists from Brazil and the US trained and participated in torture in Latin American countries. They confirmed the existence of torture schools in Brazil, Uruguay, and Chile, including the Colonia Dignidad torture school in Parral, Maule Region of central Chile.

The repressive history reveals different modus operandi have been used by repressive forces to instill terror and paralyze the popular movement. For example, after the first national day of protest against the dictatorship, which was called by the Copper Workers Confederation in May 1983, two people were killed and more than six hundred detained. Three days later, the Army and Carabineros conducted night raids on more than a dozen neighborhoods in the southwest of the capital of Chile, and rounded up all men for criminal record checks (La Huella, 2001).

On August 23 and 24, 1984, six members of Movimiento de Izquierda Revolucionaria (MIR) were assassinated in the south of Chile by the CNI, in an operation known as Alpha Carbon 1 (Carmona, 2014). On June 15 and 16, 1987, twelve members of the Manuel Rodriguez Patriotic Front were assassinated in Santiago by the CNI, in what is known as the Corpus Christi killings (Aguilera, 1996; Sagaris, 1996).

The above are only a handful examples of the thousands of acts of political repression undertaken by the Chilean dictatorship between 1973 and 2000. As noted earlier, the Chilean state repressive apparatus was also active outside the country. Operation Condor, for example, is a well-known operation in which the external department 
of DINA coordinated a counter-revolutionary alliance with the intelligence services of the military dictatorships of Argentina, Uruguay, Paraguay, Bolivia, and Brazil (Roth-Arriaza, 2005). To stop the growth of revolutionary groups in the continent they agreed to share information, exchange captives, and coordinate their activities both bilaterally and on a regional level (Guardiola-Rivera, 2013; Mendes, 2006; RothArriaza, 2005). As a result, thousands of Latin Americans-among them hundreds of Chilean activists - were detained, exchanged, tortured, killed and their bodies disappeared (Roth-Arriaza, 2005). The external department of DINA was also active outside of Latin America. In close ties with Italian fascists and anti-Castro Cubans in the US, they attacked and assassinated Chilean exiles in Rome and Washington (Agger and Jensen, 1996; Guardiola-Rivera, 2013; Mendes, 2006; Roth-Arriaza, 2005).

The political violence used by the dictatorship inside and outside Chile is well documented. After 1990, two governmental commissions investigating human rights abuses committed by the dictatorship were set up. The first one, the Commission on Truth and Reconciliation (also known as the Rettig Report), submitted its report in March of 1991. It identified a grim panorama of repression, documented more than 2,000 deaths, and criticized the judiciary for its complicity with the military regime. In response, the government presented a compensation scheme for victims of political repression but failed to bring the perpetrators to justice (Collier and Sater, 2004). A second report by the Valech Commission found that more than 40,000 people experienced direct political repression during the dictatorship (Delano, 2011) . $^{5}$

The physical and psychological effects of political violence are serious and long lasting. The long-term effects experienced by victims of torture include a variety of acute medical symptoms such as gastrointestinal disorders, lumbar spine abnormalities, skin lesions, severe headaches, and hearing deficits. These problems are often accompanied by pronounced mental symptoms such as depression, anxiety, insomnia, and nightmares, post-traumatic stress disorder, as well as what some have called the torture syndrome (Blackwell, 2005; Conroy, 2000; Dawes, 2013; Elsass, 1997; Gerrity et al., 2001; Sánchez, 2007).

\section{Violence and Privatization}

Between 1973 and 2000, the military ruled over the working class with bayonets while economic affairs were led by a group of economists trained at the University of Chicago and at the Pontificia Universidad Católica de Chile, known as the Chicago Boys. With Milton Friedman at its helm, the University of Chicago represented the now well-documented heart of a burgeoning new orthodoxy of monetarism and unre-

5. This number includes the people who disappeared after being detained by the military police, who were tortured and executed, and political prisoners accredited by this commission. It does not include exiles and the families of those affected by repression. 
strained capitalism (Collier and Sater, 2004). The alliance between the military and the Chicago Boys made Chile a laboratory where the neoliberal economic model was first tested (Wahl, 2011).

The Chicago Boys embarked on a neoliberal reform program that included laying off tens of thousands of workers; significantly reducing bargaining rights; privatizing profitable state companies; lowering taxes and tariffs; eliminating government subsidies; reducing public spending by more than a quarter, facilitating the privatization of government social services such as health, education and social security; and closely controlling the money supply (Collier and Sater, 2004; Rosenfeld, 1994; Sagaris, 1996; Tochman, 2010).

The predictable result of these economic measures was a deep recession, with unemployment reaching 20 per cent and real wages falling to three-fifths of their 1970 level (Collier and Sater, 2004). These harsh effects would not have been tolerated by the Chilean working class in a democratic society. However, as Wahl (2011) notes, the systematic political repression "of the trade union and labour movement was so extensive that the restructuring of society could be carried out without too much resistance" (p. 45).

The testimony that Sergio Tomasella gave before Argentina's True and Reconciliation National Commission is pertinent to our linking of capital, political repression, and the creation of physical and psychological trauma. Tomasella said that the suffering of those who experienced political repression cannot and should not be isolated from the economic interests served by the breaking of their bodies and the destruction of their activist networks (Klein, 2010). That is, the brutal treatment of the population permitted the economic changes that provided enormous economic rewards to the capitalist class.

One of the economic measures taken by the military was the privatization of more than 400 state-owned, state-controlled, or "intervened" companies. The privatization of state companies was a disguised subsidy given to corporations at a time when the government was drastically reducing public spending. For example, the sale of the state-owned Pacific Steel Company, with assets greater than \$200 million was sold for less than $\$ 50$ million. That is, in only one transaction, the state subsidized private buyers to the tune of more than $\$ 150$ million (Monckeber, 2002)

The same individuals appointed by the dictatorship to manage state companies became owners or administrators when the companies were sold to private hands (Monckeber, 2002). An example of this is the sale of a nitrate mining concern (Soquimich) in which Julio Ponce, the former son-in-law of Pinochet led the transition from state- to privately-owned company and was its CEO until very recently (Fazio, 2005;

6. All dollar amounts are in US funds. 
Monckeber, 2002). He was forced to resign as CEO when a number of political bribe scandals involving Soquimich became public in 2016.

Fazio (2005) notes that Soquimich is an example of the formula designed during the military dictatorship to transfer public companies to business people who acquired them with relatively little capital. Ponce Lerou, for example, acquired Soquimich for 24.96 per cent of its value. It is important to note that since 2001 the largest shareholder of Soquimich is the Potash Corporation of Saskatchewan-itself a former public company-with 24.99 per cent of the total shares (Fazio, 2005).

The dictatorship and post-dictatorship governments have shown a determination to protect powerful local and foreign economic interests. For example, in the case of Chile's copper reserves, to this day, the state legally has exclusive and sole rights for exploitation. However, private companies (mainly transnationals) regained control over 70 per cent of Chilean nationalized copper minerals, particularly after the return to "democracy" (Riesco, 2008). Chile's Copper Corporation (Codelco), one of the few remaining state-owned companies, controls the remaining 30 per cent (Walder, 2009). For Riesco (2008, p. 1) it is scandalous that most private companies since the 1990s "had operated over a decade without paying any taxes at all-even worse, they had accumulated billions in tax credits." After the return of elected governments in the 1990s, private mining companies were allowed to use a tax evasion scheme through which foreign companies earned billions of dollars and did not pay a single dollar in taxes until 2002. In 2005, the state-owned Codelco paid 72 per cent of the total tax money collected by the state for copper mining while producing 32 per cent of the output. In that same year, private companies paid 28 per cent of the total tax money while their share in copper production was 68 per cent (Riesco, 2008).

The amount of profit made by multinational corporations during and after the dictatorship explains their fervent support for the violent overthrow of the Allende government. Before 1973, copper produced by US corporations generated "the equivalent of over half of Chile's total assets accumulated over the previous 400 years" (Collins, 1974, p. 179). In two years, 2006 and 2007, they obtained more than $\$ 40$ billion. This is double the total invested by private mining companies in Chile from 1974 to 2006, and represented 60 per cent of the national budget for each of those years (Salazar, 2009; Walder, 2009).

This plunder has continued in the current period, and multinationals and local companies still receive huge financial benefits to the detriment of the working class. In the first trimester of 2010 alone, private corporations increased their profits by 40 per cent, reaching USD \$2,185 billion (Walder, 2010). A report tracing Foreign Direct Investments (FDI) from 1996 to 2011 reveals the level of profitability of foreign investment in Chile. In 2007, FDI amounted to USD \$ 1,369 billion. The amount 
extracted by multinational corporations and foreign investors in return was USD $\$ 18,856$ billion, or a profit of 1,277 per cent (Punto Final. Editorial, Septiembre 2012).

In the early 1980 s, the Chilean people started to defy repression and began massive demonstrations and bold military actions. For example, in September 1986, Manuel Rodriguez Patriotic Front almost executed Pinochet, the most guarded person in the country, in a brilliant military operation. Alarmed by these developments, and in order to prevent another Nicaragua or Cuba on the continent, the US government persuaded the dictatorship to negotiate a transition to a more acceptable regime. Thus in 1990, an elected government began to administer the capitalist state.

\section{Democratic Violence and the Continued Occupation of Mapuche Territory}

The presence of an elected government meant the end of political repression for most Chileans, but not for all. In this second, post-dictatorial period, capital expansion has been linked to the continuation of psychological trauma until this day. Loyal to the compromise between the armed forces and the opposition, all post-dictatorship governments have worked to preserve the main legislative and economic legacy of the dictatorship ${ }^{7}$. This is the case with developments to the forest industry, which was initiated by the dictatorship and continued by its successors.

The development of the forest sector has its origin during the dictatorship under the forest subsidy (DL 701) enacted in 1974 to subsidize the operations of the major economic groups in Chile (Walder, 2009). According to CIPER Chile (2015) the subsidy provided $\$ 875$ million to the forest sector between 1974 and 2014. From this $\$ 875$ million the Angelini and Matte groups received $\$ 600$ million, effectively subsidizing two of the richest families in the world at the expense of the Chilean people (Walder, 2009). The forestry industry is firmly anchored in 3.6 million hectares of ancestral land claimed by the indigenous Mapuche people, who demand that their land be returned to them (Walder, 2009).

In the forest industry, the dictatorship applied the same process of privatization utilized in the copper industry. Between 1976 and 1979 the state privatized six major forest companies. They were all sold to private groups for 78 per cent of their real value (Zibechi, 2007). Angelini and Matte represent the two largest economic groups in the forest industry and were the beneficiaries of that sale. Araya holds that the development of the forest industry is one of the most visible processes of the new

7. Parties elected since 1990 are the centre-right Concertacion (1990-2010); the right-wing Alianza Democratica (2010-2014); Concertacion, this time reformulated as the Nueva Mayoria (2014-2018); and, Alianza Democratica, now reformulated as Chile Vamos (2018-present).

8. The Angelini group bought Celulosa Constitucion and Celulosa Arauco and the Matte group bought the Inforsa Company. In 200-2005, the Angelini group had an income of 2.5 billion dollars and the Matte group and income of 1.3 billion dollars. 
economic model imposed by the dictatorship, and the second most important activity in the Chilean economy (Araya, 2003; Henne and Gabrielson, 2015). For example, in 2009 the forest industry had exports estimated at more than $\$ 4.5$ billion (Walder, 2009) and $\$ 6.094$ billion in 2014 (CIPER Chile 2015). Most of the profit went to the Angelini and Matte groups. Matte group had revenues of $\$ 1.17$ billion in the first trimester of 2009 and Angellini group's revenue was more than $\$ 1,5$ billion (Walder, 2009).

The forest sector, which provides a key source of revenue for some of Chile's largest economic groups, is also the source of one of the most important social and political conflicts in Chile today. The Mapuche consider this development a new form of intervention. "First, alcoholism...the civilization...the evangelization and now the forest companies. Other type of weapon to exterminate the communities" (Araya, 2003, p. 9). Seguel (2007) holds that the forest industry is systematically damaging the water and vegetation, which results in environmental changes caused by the progressive erosion of the soil, alterations of the hydraulic cycle, and increasing contamination. In addition, Zibechi (2007) notes that the invasion of timber and hydroelectric companies onto the Mapuche lands has caused an exponential increase in poverty and migration.

The development of the forest industry and its negative consequences for the Mapuche characterize this current period as one in which the Mapuche nation again stands to defend its territory. Klubock (2014) notes that in the 1990s a robust Mapuche movement emerged from the Mapuche communities to challenge the dominion of the forestry companies, in the south of Chile. As such, they become the object of repression and subjected to politically motivated physical and psychological trauma. However, Seguel (2007) notes that many communities are fighting back to avoid extermination. Zibechi (2007) says that out of desperation many communities re-occupy lands stolen by the timber companies, continuing the fight which began when the colonizers invaded their territory in the 1500s. According to Paley (2010), given that their demands for recognition of land rights are not yet recognized, the Mapuche people organize against transnational corporate activities in their territory. Currently, they are trying to recover lands that were returned to Mapuche ownership during the agrarian reform of the early 1970s but later confiscated by the dictatorship and sold to the forest companies. Mapuche organizations such as the Coordinadora Arauco Malleco (CAM) consider this an injustice and are not willing to accept the government's position any longer.

For the Chilean anti-dictatorial movement, the early 1980's marked the beginning of a new stage in the fight against Pinochet. Similarly, for the Mapuche the burning of three trucks owned by a forest company in Lumaco in 1997 marked the renewal of the independent Mapuche movement for self-determination and national liberation (Huenchunao, 2014; Pairican 2013). 
Several authors, provide accounts of some of the direct actions taken by the Mapuche (Paley, 2010; Tockman, 2010; Wadi, 2014; Zibechi, 2007). These actions include public demonstrations, burning timber plantations, and land occupations. Pairican (2013) notes that the government, when confronted with land recuperations and the burning of forest plantations, decided in 2001 to deal with the Mapuche's demands as a security problem. Thus, the government uses the police, courts, and third parties to repress every Mapuche manifestation (Seguel, 2007). This strategy is the same as the one used in Guatemala, where according to Paley and Granowsky-Larsen (2018) criminalization and repression are used to undermine the legitimate reivindication of indigenous people.

The main repressive apparatus used against Mapuche organizations are the Carabineros. Although the DINA-CNI are no longer active their tactics and procedures remain in effect. For example, Carabineros launched Operación Paciencia, which unified the military and police units operating in Mapuche territory under one command. The officers in charge of intelligence in each zone became an advisory group. Then, the most conflictive communities were surrounded by mobile military intervention groups (Pairican, 2013). The self-determination movement was thoroughly investigated and CAM became the focus of repression as it was characterized as an "insurrectional" organization seeking an "indigenous uprising" (Pairican, 2013). Following this characterization, sixteen CAM members "were put on trial for belonging to the "terrorist" Coordinadora Arauco-Malleco for "illicit terrorist association"” Klubock (2014, p. 297).

Another instrument of repression is Hernan Trizano Command, a paramilitary group composed mainly of landowners, which promises reprisals against indigenous people and defend landowners and forest and hydroelectric companies (Pairican, 2013).

In addition to the political violence that comes with the militarization of the Mapuche territory, the government prosecutes Mapuche activists in both civil and military courts, and continues to apply Pinochet's anti-terrorist legislation. A slightly modified version of the anti-terrorist law enacted by the dictatorship in 1984 began to be applied to the Mapuche struggle in 2001. For example, this law allows the prosecution to use "faceless" witnesses whose identities are withheld from the public and who are paid and protected by the state in exchange for their testimony. The defense does not have the right to hear the testimony of the secret witnesses until the trial, and defense lawyers' phones can be tapped legally.

Wadi (2014, p. 2) notes that: "The anti-terror legislation has been manipulated and utilized, in particular, by Michelle Bachelet's government as the means to criminalize Mapuche resistance". This is particularly aimed at the leaders, as a strategy to neutralize their demands for land (Aylwin et al., 2013). Llaitul, a Mapuche leader and former 
political prisoner, provides a reason for the application of the anti-terror law: "we represent the fight against those who control the economic power and manipulate the political institutions" (Llaitul and Arrate, 2012, p. 140).

Ben Emmerson, a United Nations Special Rapporteur on human rights and counter-terrorism, visited Chile and urged the end of the application of the anti-terrorism law, arguing it discriminates against Mapuche people and stigmatizes and delegitimizes their land claims and protests (UN News, 2013). Political Repression in Mapuche territory has resulted in hundreds of people detained, prosecuted and sentenced; dozens injured; and at least five activists killed during direct actions repressed by the police or the military (Seguel, 2007). According to the AzkintuWE Mapuche publication, Carabineros torture children, elders, and adults. The Wallmapuwen political party (2010) considers that the police violence against defenceless communities, including elders and children; the torture and humiliating treatment against the detained; and the recurrent beatings, demonstrate that the Mapuche are considered second class citizens in Chile. No other sector of the Chilean population is treated in this way by the state and its institutions.

Amnesty International-USA described the police violence carried out against one Mapuche community in Ercilla, on July 23, 2012. The violent eviction of the community from its reclaimed traditional land resulted "in a dozen Indigenous community members-including children-being detained, with many suffering injuries...At least four other Mapuche children were injured when police fired buckshot at demonstrators who had gathered outside Collipulli Hospital, where the injured friends and family members had been taken" (Amnesty International, 2012, p. 1).

Jonathan Huillical and Felipe Huenchullan are two of the many Mapuche militants who have been tortured. The torturers wanted to extract information from them to incriminate other Mapuche people accused of being CAM members (Garcia-Huidobro, 2011). The most recent case of torture was against Lorenza Cayuhan, a Mapuche political prisoner who was forced to deliver her baby Sayen while wearing shackles, at a hospital in Concepción on October 12, 2016. The National Institute of Human Rights and the Medical College of Chile have denounced the treatment received by this political prisoner as torture (El Mostrador, 2016).

Amnesty International annual reports have denounced the violence applied to Mapuche communities. For example, the 2013 report indicates that torture and ill treatment continue to be matters of concern and that Mapuche activists were subjected to human rights violations. The reports also note the excessive use of force including the firing of rubber bullets and the use of tear gas when responding to Mapuche mobilizations; and the unfair trials against Mapuche activists and arbitrary detentions (Amnesty International, 2013, 2016). 
The above review of the two periods during which organized violence has created psychological trauma reveals that physical and psychological torture of political opponents have been present since the arrival of Spanish invaders. Since the establishment of the Republic of Chile, the Mapuche and the Chilean working class and their allies have borne the brunt of capital's violence. They became the targets of political repression during the two periods covered in this review, when the poor Mapuche peasantry, in alliance with other poor peasants, started a process of reivindication, mobilization, and land recuperation. Then, in conjunction with other working class mobilizations taking place at the time (1970-1973), they brought the Chilean state's model of gradualist change into crisis (Mallon, 2005).

Today, in particular, Mapuche communities and organizations are at the forefront of the struggle against the interests of the forest companies operating in the south of Chile, and as such they are the targets of the massive and selective political repression encouraged by all the elected post-dictatorship governments.

The Army and the police have been the preferred instruments used to protect and advance the interests of the national and international companies that exploit Chile's natural and human resources. In fulfilling this role, the Army and the police physically and psychologically castigate those who dare to challenge the profit driven objectives of the dominant class.

During this time, the respect of individual and collective human rights has depended on the level of a person or group's agreement with capital expansion. In both periods political violence was used against individuals and communities. In the first period, the targets of political repression were the Chilean working class and popular movements including the Mapuche population. In the second period, political repression has been focused on Mapuche communities and their leadership.

\section{Conclusion}

The Chilean and international capitalist class used organized violence to protect the capitalist system in 1973, and with brutal state repression and free market economics developed a neoliberal model that became the ideal which other capitalists have followed in their own countries (Tockman, 2010).

The financial rewards violence provides the capitalist class are clear. The profits derived from the privatization of state companies, the exploitation of copper reserves and the exploitation of Mapuche lands by the forest industry are not benefiting the working class or the Mapuche people. The change from the dictatorship to elected governments has not made much of a difference for the working class and the Mapuche. Just as in the 1500s, the Mapuche people are being forced to resist the appropriation and environmental degradation brought about by the forest industry in their ancestral lands. 
Politically-motivated violence such as torture causes serious and long-lasting psychological trauma. The lack of studies documenting the effects of torture on the Mapuche people is one of the scholar task that needs to be undertaken in the very near future. However, this gap in the literature, does not mean the Mapuche people who experience torture do not suffer the same or similar effects reported by people from other groups. The psychological trauma experienced by Mapuche activists and communities demanding their ancestral lands stems from the resistance their people begun in the 1500s. Similarly, the psychological trauma experienced by Chilean social and political activists during the dictatorship stems from the struggle the Chilean working class began for better living conditions in the early 1800s. Many members of the Mapuche people and many members of the Chilean working class oppose the expansion of capital in the Wallmapu and Chile today.

These two struggles, though onerous in terms of the physical and psychological damage brought against participants, will provide both peoples the wisdom to see their struggles as complementary and not antagonistic. When such a unification occurs, the unjust system that oppresses both populations will be defeated. Then Tomasella and the thousands of Chilean and Mapuche activists who have suffered torture will know that the pain, terror, and suffering inflicted on their bodies and psyches did not paralyze the struggle. Alejandro's people would have then realized his dream of creating and living in a more humane society.

\section{References}

Agger, I., and Soren, J. (1996). Trauma and Healing under State Terrorism. Zed Books. Aguilera, O. (1996). Operacion Albania-sangre de Corpus Christi. Unknown Publisher. Amnesty International Report: The state of the world's human rights. Amnesty International Ltd.

Amnesty International Report (2013). The state of the world's human rights. Amnesty International Ltd.

Amnesty International USA. (2012). Chile: Indigenous Children among the Injured After Violent Eviction. Recuperado de http://www.amnestyusa.org/news-item/ chile-indigenous-children-among-the-injured-after-violent-eviction.

Araya, J. (2003). La invasión de las plantaciones forestales en Chile. Efectos de la actividad forestal en la población indigena mapuche [The invasión of forest plantations in Chile: Effects of the forestry industry on the Mapuche population]. Observatorio Latinoamericano de Conflictos Ambientales.

Aylwin, J., Yanez, N., and Sanchez, R. (2013). Pueblo Mapuche y Recursos Forestales en Chile: Devastación y Conservación en un Contexto de Globalización Económica [Mapuche people and forest resources in Chile: Devastation and conservation in a globalized world]. Observatorio Ciudadano. IWGIA. 
Barudy, J., Serrano, J., and Martens, J. (1980). Problemas psíquicos provocados por la tortura en los refugiados políticos latinoamericanos. In Barudy, J., Basiagla, F., Bonami, M., Corral, N., Duran, E., Martens, J., Murillo, A., Paez, D., Serrano, J. Eds. Asi buscamos rehacernos. Represión, exilio, trabajo psico-social. Edición conjunta: Colectivo Latinoamericano de Trabajo Psicosocial COLAT and Comisión Evangélica Latinoamericana de Educación Cristiana.

Barudy, J., and Paez, D. (1979). Salud mental y exilio político: la búsqueda de una terapia liberadora[Mental health and political exile: looking for a liberating therapy]. In Lecturas de Psicologia y Politica. Crisis Política y Daño Psicológico, vol. 2. Santiago: Colectivo Chileno de Trabajo Psicosocial.

Blackwell, D. (2005). Counselling and Psychotherapy with Refugees. Jessica Kingsley Publishers.

Boorstein, E. (1987). An Inside View...Allende's Chile. Fifth edition. International Publishers Co.

Cademartori, J. (2000). A treinta años del triunfo de la Unidad Popular. Web del Centro de Estudio "Miguel Enriquez."

Carmona, E. (2014, August). El terrorismo de estado que vivió Chile [State terrorism that Chile lived]. Punto Final. 48 (810).

CIPER Chile. (2015). Colusión del papel liquida subsidio que beneficia por décadas al Grupo Matte[Colusión in the paper industry ends state subsidy that for decades benefits the Matte group. CIPER Chile. www.ciperchile.cl/2015/11/10/colusiondelpapelliquidasubsidio que-beneficia-por-decadas-al-grupo-matte/.

Collier, S., and Sater, W. (2004). A History of Chile, 1808-2002. (2nd ed.). Cambridge University Press.

Collins, J. (1974). Tightening the Financial Knot. In L. Birns (Ed.), The End of Chilean Democracy. New York: The Seabury Press.

Conroy, J. (2000). Unspeakable Acts, Ordinary People: The Dynamics of Torture. University of California Press.

Dawes, J. (2013). Evil Men. Harvard University Press.

De la Pena, A. (1994). Manual de Historia de Chile. Santiago: Ediciones Occidente.

Delano, M. (2011, August). Chile reconoce a más de 40.000 víctimas de la dictadura de Pinochet. Diario El País.

El Mostrador. (2016). INDH denuncia tortura contra mapuche que pario con grilletes.

Elsass, P. (1997). Treating victims of torture and violence: Theoretical, cross-cultural, and clinical implications. New York University. 
Fazio, H. (2005). Mapa de la extrema riqueza al año 2005. Santiago: LOM Ediciones. Garcia-Huidobro, L. (2011, August). Cómo condenaron a los dirigentes mapuche. Le Monde Diplomatique (Chilean edition) 121.

Gerrity, E., Keane, T., and Tuma, F. (Eds.). (2001). The Mental Health Consequences of Torture. Academic/ Plenum Publishers.

Guardiola-Rivera, O. (2013). Story of a Death Foretold. The Coup against Salvador Allende. London: Bloomsbury.

Henne, A., and Gabrielson, T. (2015). Chile is Timber Country Citizenship, Justice and Scale in the Chilean Native Forest Market Campaign. In Alex Latta and Hannah Wittman (Eds.), Environment and Citizenship in Latin America: Nature, Subjects, and Struggles (pp. 149-167). New York: Berghahan Books.

Hite, K. (2005). Estadio Nacional: Monumento y lugar de conmemoración. In P. Verdugo (Ed.), De la tortura no se habla: Aguero versus Meneses. Santiago: Catalonia.

Huenchunao, J. (2014 October). Resistencia del Pueblo Mapuche. La Lucha por Territorio y Autonomía. Le Monde Diplomatique (Chilean edition).

Klein, N. (2010). The Shock Doctrine. Toronto: Random House Canada.

Klubock, T. (2014). La frontera: forest and ecological conflict in Chile's frontier territory. Duke University Press.

La Huella. (2001). La Sórdida Guerra de los Agentes CNI: La Dramática Cronología del Periodo 1977-1990 [The sordid war of the CNI agents: The dramatic chronology of the period 1977-1990]. Santiago: Impresiones Nórdicas.

Llaitul, H., and Arrate, J. (2012). Weichan: Conversaciones con un Weychafe en la Prisión Política. Santiago: CEIBO Ediciones.

Loveman, B., and Lira, E. (2005). Marco Histórico: Terrorismo de Estado y Tortura en Chile [Historical contexto: state terrorism and torture in Chile. In Patricia Verdugo (Ed.), De la Tortura No Se Habla: Aguero versus Meneses. Santiago: Catalonia.

Mallon, F. (2005). Courage tastes of blood the Mapuche community of Nicolas Ailio and the Chilean state 1906-2001. Duke University Press.

Marradi, A., Archenti, N., and Piovani, J. (2007). Metodologia de las Ciencias Sociales. Emecé Editores.

Mendes, J. (2006). Bajo las Alas del Cóndor. Havana: Editorial Capitan San Luis.

Miliband, R. (2016). The Coup in Chile. How the Reasonable Men of Capitalism Orchestrated Horror in Chile 46 Years Ago Today." The Jacobin, September 11. Recuperado de https://www.jacobinmag.com/author/ralph-miliband.

Monckeberg, M. (2002). El Saqueo de los Grupos Económicos al Estado Chileno. (7th ed.). Santiago: Empresa Periodística La Nación. 
Moniz, L. (2008). Fórmula para el Caos: El Terror en Chile y la Caída de Salvador Allende, 1970-1973. Santiago: Editorial Debate.

Moyano, A. (2008). Crónicas de la Resistencia Mapuche [Chronicles of the Mapuche resistance]. (2nd ed.). Buenos Aires: Cooperativa Chilavert Artes Gráficas.

Pairican, F. (2013 March). Rutas Mapuches hacia la Autodeterminación. Le Monde Diplomatique (Chilean edition).

Paley, D. (2010). The Roots of Mapuche Resistance. Vancouver Media Co-op, September 18. Recuperado de http://vancouver.mediacoop.ca/fr/story/roots-mapucheresistance/4671.

Paley, D., and Granowsky-Larsen, S. (2018). Organized violence and the expansion of capital. In D. Paley, and S. Granowsky -Larsen (Eds.), Organized violence: capitalist warfare in Latin America. University of Regina Press.

Partido Mapuche Wallmapuwen. (2010 July-August). 50 Días en Huelga, 50 Días de Dignidad Nacional. Azkintuwe: El Periódico del País Mapuche 43.

Petras, J. (n.d.). The Crimes of Allende. Canadian Dimension, 9 (7-8), 9-13.

Punto Final. (2012). Editorial. La independencia inconclusa (The unfinished independence). Punto Final \# 766.

Raptis, M. (1974). Statism or Self-Management? What Kind of Socialism in Chile? Our Generation 10 (2).

Riesco, M. (2008). On mineral rents and social development in Chile." UNRISD Workshop on Social Policy in Mineral-Rich Countries. Geneva. Recuperado de https:// docs.google.com/document/preview?id=1irnZXR2apvN1pJXfNE8rSOjkEEbr cX8-n2GGy1m4-qo.

Rosenfeld, S. (1994 August). The Myth of the Chilean Miracle. Multinational Monitor. Recuperado de http://multinationalmonitor.org/hyper/issues/1994/08/ mm0894_12.html.

Roth-Arriaza, N. (2005). The Pinochet Effect: Transnational Justice in the Age of Human Rights. Philadelphia: University of Pennsylvania Press.

Sagaris, L. (1996). After the First Death: A Journey through Chile, Time, Mind. Toronto: Somerville House Publishing.

Salazar, M. (2009 September). Un día en septiembre, 39 años atrás (A day in september, 39 years ago). Punto Final \# 693.

Salazar, M. (2009). La nueva derecha que apoya a Piñera [The new right that supports Pinera]. Punto Final \# 699. 
Sánchez, M. (1996). Comparison of the psychological trauma experienced by victims of politically motivated torture and battered women. The University of Regina (Canada). Proquest Dissertation Publishing, 1996. MM 14578. Recuperado de https:// www.proquest.com/docview/304259531?pq-origsite=primo\&accountid=13480.

Sánchez, M. (2007). Physical and Psychological Effects of Politically Motivated Torture of Chilean Refugees. SPR Working Papers 21. Social Policy Research Unit. Faculty of Social Work, University of Regina.

Seguel, A. (2007). Invasión forestal y etnocidio Mapuche [Forest invasión and Mapuche ethnocide]. In Carlos Contreras (Ed.), Actas del Primer Congreso Internacional de Historia Mapuche. Nuke Mapuforlaget.

Soto, H. (2008). La Nacionalización Traicionada [Nationalization betrayed]. Punto Final 42 (665).

Tockman, J. (2010). Surviving the Chilean Economic Miracle. Cultural Survival, May 7. Recueprado de https://www.culturalsurvival.org/taxonomy/term/1555/all/ feed.

UN News (2013, July 31). Chile must stop using anti-terrorism law against Mapuche indigenous group-UN expert. United Nations UN News Global Perspective Human Stories. Recuperado de https://news.un.org/en/story/2013/07/445902-chilemust-stop-using-anti-terrorism-law-against-mapuche-indigenous-group-un.

Verdugo, P. (2003). Allende: Cómo la Casa Blanca Provocó su Muerte. Santiago: Catalonia.

Wadi, R. (2014). In Chile, dismissing Mapuche resistance as terrorism. Mint Press News, August 12. Recuperado de http://mintpressnews.com/in-chile-dismissingmapuche-resistance-as-terrorism/195192/.

Wahl, A. (2011). The Rise and Fall of the Welfare State. London: Pluto Press.

Walder, P. (2010, June 25-July 8). Chile en la OECD. De cabeza de ratón a cola de león. (Chile in the OCDE. From a rat's head to a lion's tail). Punto Final, 44 (712).

Walder, P. (2009, August). Angellini and Matte owners of the Araucania [Angellini and Matte, the owners of the Araucania]. Punto Final, 692.

Westhues, A., Cadell, S., Karabanow, J., Maxwell, Linda., and Sanchez, M. (1999). The creation of knowledge. Linking research paradigms to practice. Canadian Social Work Review, 16(2), 129-154.

Zibechi, R. (2007 August). The Mapuche in Chile. Z Net. Recuperado de https:// zcomm.org/znetarticle/the-mapuche-in-chile-by-ra-l-zibechi/.

Zimbalist, A., and Stallings, B. (1973). Showdown in Chile. Monthly Review, 25 (5). 


\section{Sobre el autor}

Miguel SÁnCHEZ is an Associate Professor with the Faculty of Social Work University of Regina, Canada. Research interests: Social policy, child and family poverty, political trauma, physical and psychological effects of politically motivated torture, immigrant adaptation. E-mail: miguel.sanchez@uregina.ca. (iD) https://orcid.org/0000-0001-7670-1186 


\title{
CUHSO
}

Fundada en 1984, la revista CUHSO es una de las publicaciones periódicas más antiguas en ciencias sociales y humanidades del sur de Chile. Con una periodicidad semestral, recibe todo el año trabajos inéditos de las distintas disciplinas de las ciencias sociales y las humanidades especializadas en el estudio y comprensión de la diversidad sociocultural, especialmente de las sociedades latinoamericanas y sus tensiones producto de la herencia colonial, la modernidad y la globalización. En este sentido, la revista valora tanto el rigor como la pluralidad teórica, epistemológica y metodológica de los trabajos.

\author{
EDITOR \\ Matthias Gloël \\ CoOrdinadora EDITORIAL \\ Claudia Campos Letelier \\ Corrector de ESTILO Y DiSEÑAdor \\ Ediciones Silsag \\ Traductor, CORRECTOR LENGUA INGLESA \\ Aurora Sambolin Santiago \\ SITIO WEB \\ cuhso.uct.cl \\ E-MAIL \\ cuhso@uct.cl
}

LICENCIA DE ESTE ARTÍCULO

Creative Commons Atribución Compartir Igual 4.0 Internacional 